\title{
It is not Only About Equality. A Study on the (Other) Values That Ground Attitudes to the Welfare State
}

\section{Inés Calzada, María Gómez-Garrido, Luis Moreno and Francisco Javier Moreno-Fuentes}

Institute of Public Goods and Policies, Spanish National Research Council, Madrid, Spain

\begin{abstract}
Literature on welfare attitudes has reached a stylized scheme in which egalitarian values and self-interest concerns are the two main determinants of welfare attitudes. We aim to bring forward existing research by identifying additional values that people draw on to elaborate opinions on welfare issues. Using data from the European Social Survey 2008 and 26 countries, we find that values such as multiculturalism or authoritarianism, among others, lie at the roots of welfare attitudes. However, egalitarianism is the only value with a significant effect in all countries. Differences between welfare regimes in the values associated with welfare opinions exist but are unconnected with aggregate support for the welfare state, suggesting that this institution can achieve a high level of legitimacy on different moral grounds.
\end{abstract}

In recent years, scholars have devoted considerable effort to understand citizens' opinions toward welfare policies. Departing from an initial focus on the effect of living conditions on welfare attitudes that showed how those more in need of welfare intervention were also more prone to favor it (Andre $\beta$ \& Heien, 200I; Bean \& Papadakis, I998; Forma, I999; Svallfors, I995), research has more recently turned to the subjective grounds of people's preferences about the role of the state in welfare. In this respect, it is well known that the extent to which an individual embraces egalitarian (vs. individualistic) values has an effect on her or his opinions toward the welfare state (Achterberg, Houtman, \& Derks, 20ı ; Breznau, 20ıо; Fraile \& Ferrer, 2005; Lipsmeyer \& Nordstrom, 2003).

All correspondence concerning this article should be addressed to Inés Calzada, Institute of Public Goods and Policies, Spanish National Research Council (CSIC), C/Albasanz 26-28, Madrid 28037, Spain. E-mail: ines.calzada@cchs.csic.es 
However, the correlations of egalitarian ideology and individual interest with welfare state attitudes are not very strong (Dallinger, 20I0). This led scholars to search for additional determinants of welfare attitudes-mainly of a subjective nature - that enhance our understanding of people's opinions. An appealing, but fragmented literature emerged from these efforts where the importance of different values and beliefs in shaping welfare attitudes is tested using a variety of surveys, methods, and samples of countries. To add further complexity, the path-breaking work of Rothstein (I998) on moral institutionalism convincingly argued that different forms of organizing welfare programs foster different values among the population, and these values in turn erode or reinforce the legitimacy of the welfare system.

In this article we analyze the joint effect on welfare attitudes of five subjective factors that previous theoretical or empirical works found significant for this topic: Multiculturalism, merit, authoritarianism, gender traditionalism, and generalized trust. In addition, we try to empirically corroborate the moral institutionalism notion that the design of welfare institutions shapes the values and beliefs people use to elaborate opinions about the welfare state. To classify countries according to the guiding principles that best describe their national welfare systems we follow Rothstein (I998), the wellknown classifications of Esping-Andersen (I990, I999) and Korpi and Palme (I998), as well as literature on Mediterranean welfare systems (Bonoli, I997; Ferrera, I993; Moreno, 2006). We use the European Social Survey 2008 and data for 26 European countries.

The aim of our article is to provide evidence that help to answer three questions:

I. Do the five subjective factors identified by the previous literature have a statistically significant effect on welfare attitudes across all European countries?

2. Do all five subjective factors remain important after controlling for each other, and for the two established determinants of welfare attitudes (selfinterest and egalitarianism)?

3. Is there a correlation between the values and beliefs associated with support for the welfare state and the guiding principles of the welfare system in each country?

Results can be useful for scholars interested in the subjective factors that affect citizens' opinions to welfare programs across Europe.

\section{Theoretical Framework}

In the past 20 years, scholars have agreed on the existence of two general (but non-exhaustive) determinants of welfare attitudes: The economic gain citizens 
make (or expect to make) from welfare programs - the "self-interest factor" and their ideological stance regarding distributive justice - the "ideology factor"-(Andreß \& Heien, 200ı; Breznau, 20ıо; Forma, I999; Gelissen, 2000; Lipsmeyer, \& Nordstrom, 2003; Svallfors, 2003). To measure the "interest" that one individual has in the welfare state indicators of social class such as income, occupation, or educational attainment are commonly used (Andre $\beta$ \& Heien, 200I; Bean \& Papadakis, I998; Forma, I999; Svallfors, I995). Regarding the operationalization of the "ideology" factor, some scholars use indicators of political ideology like an individual's self-placement on the leftright scale (Fraile \& Ferrer, 2005), or the vote for Conservative/Liberal parties vs. Social-democratic ones (Lipsmeyer \& Nordstrom, 2003). Other authors prefer to include survey questions related to economic egalitarianism or to redistribution (Achterberg et al., 20II; Blekesaune \& Quadagno, 2003; Luo, I998).

The two-factor scheme has shown its usefulness across time and countries, with the drawback that, in most countries, the correlations of welfare attitudes with "interest" and "egalitarianism" are not very strong (Dallinger, 2010). Scholars have tried to solve this shortcoming following various approaches. On the one hand, efforts have been made to widen the conception of selfinterested motivations to support welfare programs. Going past social class, a number of works compare the opinions toward the welfare state of groups depending on their relation with welfare programs. From these studies we know that gender and age-cohort shape opinions toward child-care or old-age pensions welfare programs (Blekesaune \& Quadagno, 2003; Goerres \& Tepe, 2010; Marcum \& Treas, 20I2; Svallfors, I995). Iversen (2005) demonstrates that job skills also play a role in the formation of welfare attitudes, showing that workers with specific skills are more inclined to support a high level of state protection than those with general skills. ${ }^{1}$ Even if we take into account these new cleavages, most of the variance in welfare attitudes remains nevertheless unexplained. This led scholars to go past the two-factor scheme and reflect that individuals may rely on values and beliefs other than egalitarianism when they develop an opinion on the welfare state.

\section{Research on the Values and Beliefs that Structure Welfare Opinions}

The idea that values and general beliefs are scaffolds people use to elaborate their political attitudes is well established in public opinion research. Contrasting Converse's (1964) pessimistic view about the inconsistence and randomness of individual political attitudes, a number of authors (Feldman, I988; Feldman \& Zaller, I992; Sniderman, Brody, \& Tetlock, I99i) have

\footnotetext{
${ }^{1}$ The author explains this pattern by the lower portability of specific skills, which increases fears of unemployment and makes this category of workers more willing to support state insurance.
} 
demonstrated that specific political attitudes are constrained by beliefs that are more abstract. In Peffley and Hurwitz (I985, p. 885) words: "Respondents demonstrated an integrated belief system which should permit them to link abstract principles to specific applications." Qualitative studies on opinion formation shed similar results (Brugidou, 2003; Gamson, I992). To make sense of citizens' political attitudes it seems essential to detect the general beliefs and values that structure the opinions to each issue, ${ }^{2}$ but we are still far from having a clear picture of the main values and beliefs that structure attitudes to the welfare state. In this article we study five values or beliefs that different scholars have found relevant to understand citizens' opinions toward welfare. We carried out a thorough literature review to identify the subjective factors that showed more promising results in previous works. Although we were unable to include in our analyses all perspectives, we believe that the five values and beliefs we selected represent the main approaches in the search for new subjective determinants of welfare attitudes.

A salient topic in recent literature on welfare attitudes is the increasing ethnic heterogeneity of European countries, regarded as a paramount challenge for the European Social Model (Alesina \& Glaeser, 2004). Correspondingly, conflicts between multicultural and egalitarian values have received particular attention. As Kymlicka points out, the concern is that ethnic diversity makes more difficult to generate the feelings of national solidarity presumably required to sustain redistributive policies. Additionally, multicultural policies, through their emphasis on protecting ethnic minorities' differences may contribute to further undermine national solidarity (Kymlicka, 2008, p. 62).

Studies evaluating the existence of a conflict between multiculturalism and the welfare state have been carried out mainly at the macro level of countries, failing to find a negative relationship between the level of immigration in a country and either the size of the welfare state (Kymlicka, 2008), the extension of fears about immigrants exploiting the welfare system (Halvorsen, 2007), or the percentage of the population that would like to exclude immigrants from accessing welfare benefits and services (Reeskens \& van Oorschot, 20I2). To our knowledge, no empirical study has put to test this conflict at the individual level (i.e., assessing the impact of multicultural values on attitudes to state intervention in welfare). As ethnocentric values can be an obstacle to the translation of egalitarianism or self-interest into support for welfare policies, we expect people holding multicultural values to be more positive toward the welfare state than people holding ethnocentric values. Our indicator of

\footnotetext{
${ }^{2}$ Although there has been some debate on the feasibility of measuring abstract constructs such as values (Kelsen, I967; Khoshkish, I974), their unquestionable importance to understand public opinion has encouraged academic endeavors in this direction. In the last decades, various authors aimed to create a systematic measurement of values and detect those more relevant to understand social phenomena (Hofstede, I9 80 , I998; Inglehart, I990, I997; Rokeach, I973; Schwartz, I992, I994). Given the empirical grounding of all these works, similarities of the resulting value classifications are surprisingly small.
} 
multiculturalism (vs. ethnocentrism) is elaborated with three items from European Social Survey (ESS) 2008 that ask about the perceived effect of immigration in the country's economy, in the country's cultural life, and in the general quality of life (Table I shows question wording).

A second line of research exemplified by Forma and Kangas (I999) points at the role of distributive principles as a fundamental base for attitudes toward welfare programs. Public benefits and services can be distributed according to need, citizenship or merit, and beliefs about the fairness of each possible distribution can explain support for different welfare programs within a country and across nations. In our study we cater for this approach with an indicator composed of two questions related to the more adequate way to distribute old-age pensions and unemployment benefits:

Some people say that higher earners should get larger (Q.I. old-age pensions)/(Q.2. unemployment benefits) because they have paid in more. Others say that lower earners should get larger (Q.I. old-age pensions) / (Q.2. unemployment benefits) because their needs are greater. Which of the three statements on this card comes closest to your view?

I. Lower earners should get a larger old-age pension/unemployment benefit than higher earners; 2. High and low earners should get the same amount of old-age pension/unemployment benefit; 3. Higher earners should get a larger old-age pension/unemployment benefit than lower earners.

The three options can be interpreted as different valuations of individual's merit in the distribution of public benefits. The first option gives priority to equality even at the cost of penalizing merit; the second option does not penalize, but ignores, individual merit; and the third one rewards merit even if it implies maintaining the inequalities created by the market. We expect our indicator of merit to affect support for the welfare state in all countries, although changing direction depending on the distributive principles embedded in the welfare system. People that consider fair to reward merit should be especially supportive of the welfare state in countries where public benefits depend on previous contributions, and correspondingly, they should be less prone to support the welfare state in countries where benefits are based on need or citizenship.

The recent electoral success of populist right-wing parties that combine a working-class voting base with anti-welfarist discourses is the point of departure of the third line of research that we integrate in our analysis. Houtman Achterberg, \& Derks (2008) examine the Dutch case to study the influence of authoritarian values on support for welfare programs, concluding that embracing authoritarian values difficult the translation of egalitarian values into support for the welfare state. The findings of Houtman et al. (2008) have not been replicated in other countries. To evaluate until what extent authoritarian values depress support for state intervention in welfare across all 


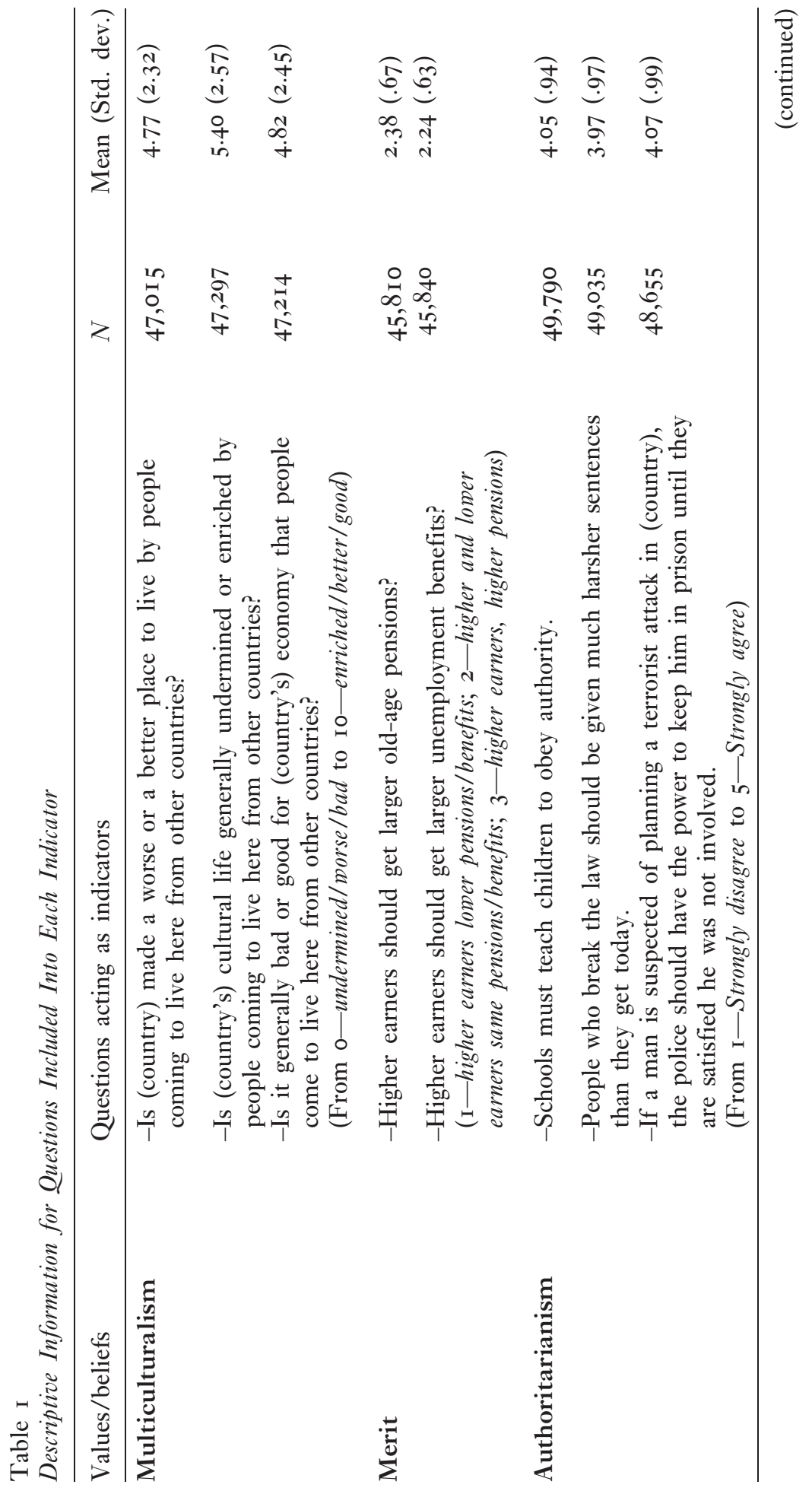

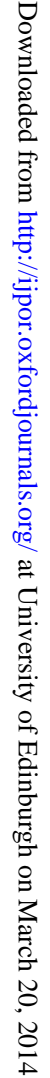




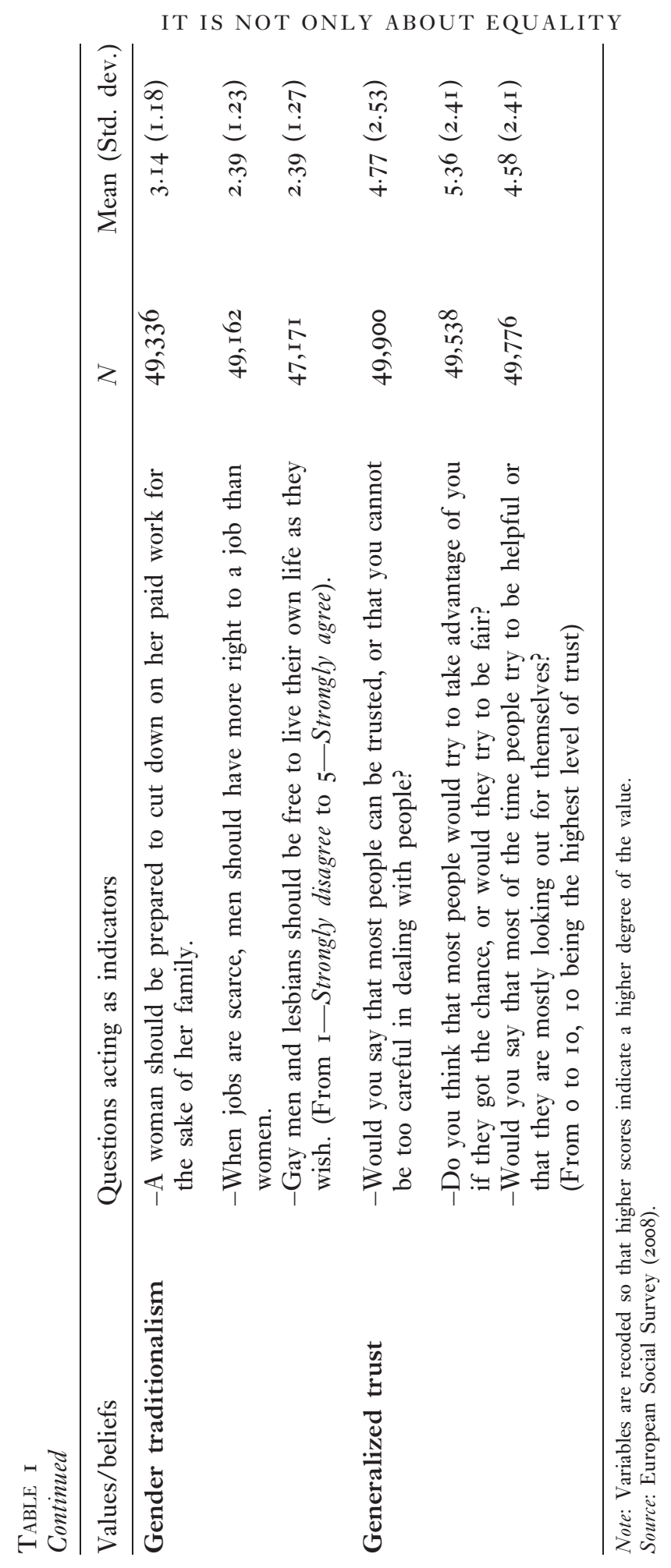


European countries, we include in our models an indicator built with three different items related to the classical definition of authoritarianism: A preference for social order vs. individual freedom (Duriez, Van Hiel, \& Kossowska, 2005; Eckhardt, I99I).

Please say how much you agree or disagree with each of the following statements: Q.I Schools must teach children to obey authority.

Q.2 People who break the law should be given much harsher sentences than they are today.

Q.3 If a man is suspected of planning a terrorist attack in (country), the police should have the power to keep him in prison until they are satisfied he was not involved.

(Answer scales from I-Strongly disagree to 5-Strongly agree).

Some welfare states, especially in the Nordic countries, have implemented family policies that aim to liberate individuals (especially women) from traditional roles (Korpi, 2000; Svallfors, I995). In contrast, Corporatist/ Continental and specifically Mediterranean welfare systems rely on the traditional family for the provision of care. Scholars on the Mediterranean welfare state point to the extension of familistic values - that imply a traditional view of gender roles - as an important factor to understand the low development of the welfare state in this area. Preferences for the traditional model of family and gender roles depress popular support for state intervention in welfare as people prefer to be cared for by women in the family rather than by public workers (Callegaro \& Passini, 2008; Reher, I998). We will assess to what extent gender traditionalism shapes welfare support across our sample (or only under certain institutional frameworks) by including an indicator built with three items of ESS 2008:

Please say how much you agree or disagree with each of the following statements: Q.I A woman should be prepared to cut down on her paid work for the sake of her family.

Q.2 When jobs are scarce, men should have more right to a job than women.

Q.3 Gay men and lesbians should be free to live their own life as they wish.

(Answer scales from I-Strongly disagree to 5-Strongly agree).

The fifth aspect included in our analysis of subjective determinants of welfare attitudes is generalized trust. Trust is considered to help "the running of a complex modern welfare state" (Taylor-Gooby, 2005, p.217) for, "if many people have the feeling that most others cannot be trusted, it will be more difficult for a community to pursue collective-action efforts and to provide for collective goods" (Hooghe, Reeskens, \& Stolle, 2007, p. 3). As with multiculturalism, the impact of generalized trust on support for the welfare state has been tested mainly at the macro level of countries. Halvorsen (2007) and van Oorschot and Arts (2005) find a positive relationship between the size of the welfare state and the extension of generalized trust. At the individual level, we 
expect that individuals with low levels of generalized trust will be reluctant to support welfare policies out of fear of misuse and free riding. At the macro level, trust is key to put to test the moral institutionalism theory, which, as we will explain later, stresses the importance of generalized trust as building block of welfare state's legitimacy in social-democratic countries. Our indicator of generalized trust employs three items that have been extensively used in the past (Sturgis \& Smith, 20Io). They ask the interviewee if she/he believes that: (a) most people can be trusted; (b) most people would try to take advantage of you if they got the chance; and (c) most of the time people try to be helpful.

The five subjective factors just detailed cannot be considered an exhaustive account of previous works. Some subjective beliefs have showed no significant relation to welfare attitudes, such as trust in the political system (Edlund, I999; Svallfors, I999), or national identification (Martínez-Herrera, 2004). Other factors such as democratic principles (Lipsmeyer \& Nordstrom, 2003) or beliefs about social mobility (Han, 20I2; Linos \& West, 2003; Luo, I998) appear to shape attitudes to welfare policies, but were not included in our analyses due to lack of adequate items in our database.

\section{The Values Embedded in the Institutional Design}

The work of Rothstein (I998) has been of prime importance to set the grounds of a theory that stresses the fundamental role of welfare policies' design to shape social norms and welfare states' legitimacy. The author starts by arguing that "citizens are likely to support a welfare state if they believe its goals to be just, (...) its implementation processes to be fair, and if they have reason to trust that most other citizens will loyally pay their taxes and not cheat the system" (Rothstein, I998, p. 220). These beliefs, in turn, are shaped by the functioning of welfare programs, arriving at the conclusion that "the design given to political institutions governs the notions of morality and justice prevailing in society" (p. 217).

Rothstein exemplifies his case comparing universal and targeted welfare states. The design of the universal welfare state favors its legitimacy in three ways. First, it is based on an aim considered fair by the large majority of the population: That the State must treat all citizens with equal concern and respect and make no discrimination among citizens. Second, access to benefits based on clear citizens' rights eases the administration of welfare programs and promotes trust in the fair functioning of public programs. Finally, the high level of taxation imposed across all income groups states that all individuals must and do share its part in the financial effort to sustain the system. By opposition, targeted welfare states can hardly claim to be guided by a nondiscrimination objective while conferring benefits only to certain groups; the administration of the programs is more complex due to the various-and sometimes ambiguous - criteria to access benefits, and programs are financed 
mostly by those who will never use them. With this design, targeted systems achieve less legitimacy than Nordic ones because their aim is not so clearly "fair" in the eyes of citizens, and because its own design provides fertile ground for distrust in the implementation of programs and in the efforts made by their beneficiaries.

In the second part of our analysis we follow this line of reasoning and expect to find a certain degree of coherence between the principles embedded in a welfare state, and the values that people draw on when they think about it. Our assumptions about the values associated with support for the welfare state in social-democratic and liberal welfare systems are based on Rothstein's arguments resumed above. We expect egalitarian people to be especially supportive of the welfare state when they live under a welfare system that clearly puts non-discrimination at the top of its guiding principles, such as the Nordic one. Rights-based rules to access benefits and a high level of direct taxation for all income groups generates the image of a system based on joint effort and mutual trust, and hence generalized trust shall feed back into the welfare state (WS) by positively affecting its legitimacy. Countries included into the Liberal regime shall be the exact opposite, with egalitarian values having a minor effect on welfare support and no role for generalized trust.

As for the rest of the countries, we rely on previous compared welfare systems studies to form our expectations. Both Esping-Andersen (1990) and Korpi and Palme (I998) characterize the Continental welfare systems as aiming more for income security than for equality, as benefits differ according to the occupational status and previous contributions of the individual. The egalitarian objective is downplayed to reward individuals' achievement in the labor market, and therefore we expect egalitarian values to present a weaker association with support for the WS than in the Nordic model, and meritocratic values to have a positive influence on support. Although Mediterranean countries have often been included in the Continental model (EspingAndersen, I990; Korpi \& Palme, I998), other authors (Bonoli, I997; Ferrera, I993; Moreno, 2006) separate these countries in a particular group due, among other things, to their mix between universal programs (health care) and contributory benefits (old-age pensions, unemployment), and their under-developed (or nonexistent) family policy. Considering this, we expect egalitarianism and merit to be positively related to support for the welfare state. As explained in the previous section, some scholars argue that a preference for family care and traditional gender roles depress support for the welfare state in the Mediterranean countries. Therefore, we expect gender traditionalism to be a depressor of support for the welfare state in this area.

The lack of comparative studies on Eastern welfare systems justifies that, following other authors (Halvorsen, 2007; Taylor-Gooby, 2004) they are placed in a sole "Eastern" group. Although these welfare systems are 
undergoing heterogeneous reforms, various authors have stressed that a mixture of egalitarian and authoritarian mechanisms characterized the social protection of this region under the communist period (Deacon, CastleKanerova, \& Manning, I992; Deacon, 2000; Manning \& Shaw, I998). If people have not changed much the elements they use to think about state intervention in welfare, we can expect a strong correlation between embracing egalitarian and authoritarian values and supporting state intervention in welfare issues.

In the final part of our analysis we expect that the values that structure welfare opinions correspond to the guiding principles of each welfare regime: Egalitarianism and generalized trust should be highly associated with support for the welfare state in the Nordic countries, and the first of these values shall present a lower impact on welfare attitudes in Liberal ones. Merit is expected to be positively associated with support for the welfare state in the Corporatist and Mediterranean regimes. Gender traditionalism may depress positive attitudes to the welfare state in the Mediterranean and, taking account of their socialist history, both egalitarian and authoritarian values should promote support for the welfare state in Eastern countries.

\section{Data and Methods}

For our analyses, we use the $4^{\text {th }}$ wave of the ESS, fielded in 2008. Our sample comprises 50.082 individuals from 26 countries. ${ }^{3}$ We build three types of variables: A dependent variable on support for the welfare state; indicators of the five values that act as explanatory variables; indicators of egalitarianism and self-interest to control for the two main determinants of welfare attitudes; and a macro variable that classify countries according to the guiding principles of their welfare states.

\section{Dependent Variable: Support for the Welfare State}

In order to measure individuals' support for the welfare state, we use van Oorschot and Meuleman (2012) index of "welfarism", constructed with questions about governments' responsibilities in the domain of welfare. The ESS 2008 includes six related items:

For each of the tasks I read out please tell me on a score of o-Io how much responsibility governments should have. o means it should not be governments' responsibility at all and to means it should be entirely governments' responsibility... ensure adequate health care for the sick?... ensure a reasonable standard of living for

\footnotetext{
${ }^{3}$ The five countries not included are: (a) Ireland, Austria, and Lithuania, because their data were not available at the time of writing this article and (b) Turkey and Israel, because of difficulties to place them in a welfare regime typology.
} 
the old?... ensure a reasonable standard of living for the unemployed? ... ensure sufficient child care services for working parents?... provide paid leave from work for people who temporarily have to care for sick family members?... ensure a job for everyone who wants one?

We checked the association of the six items through a factor analysis containing almost all questions on welfare issues available in the ESS 2008 survey. Results indicate that the six questions listed above are strongly related, so we merged them into a single indicator (weighted average of the answers to the six questions, range o-Io). Cronbach's $\alpha$ for the six elements is a satisfactory .85 .

\section{Explanatory Variables and Controls}

The first step toward building value indicators was to review the ESS 2008 questionnaire, selecting the questions that related to the values or beliefs we wanted to measure. As far as possible, we opted for questions already used as proxies of the values of interest (descriptives for all the variables in Table I). To test the validity of the indicators, we included these questions in an exploratory factor analysis pooling data for the 26 countries of our sample. As Table 2 shows, the questions are associated as expected, and the factor model explains $67 \%$ of the variance. This confirms previous works that built similar value indicators, showing that these can be used as manifestations of values rather than isolated attitudes towards particular topics. ${ }^{4}$

Using the factor model in Table 2, we computed individual scores in each of the factors. Each factor represents a value, and hence individuals' scores in each factor are used as variables. This procedure has two advantages: On the one hand, all the explanatory variables are measured in the same units (standard deviations to the European mean), and the size of coefficients can be compared. On the other hand, factors are independent from each other, and hence we can be sure of measuring the "true" effect of each value on attitudes to the welfare state.

Analyses are carried out including indicators of the two general determinants of welfare attitudes as controls. Although we are aware of its drawbacks, the education level of an individual (o-noncompleted primary, 6-second stage of tertiary) acts as a proxy for self-interest. We would have rather used family income, but this variable was not available for some countries and, when it was, the level of non-response was very high. Sex (I-male; 2-female) and age ( $15-99$ years) are also included to cater for group-specific interests. To

\footnotetext{
${ }^{4}$ To test the robustness of the indicators we replicated factor analysis with previous ESS waves (2002/ 2004/2006). We also confirmed the comparability of the instrument across countries by repeating the analysis in each individual country, and checked the construct validity of our indicators by adding different questions to the factor model and by looking at its correlations with each of the factors. The results of all three tests were satisfactory.
} 
Table 2

Factor Analysis; Rotated Matrix

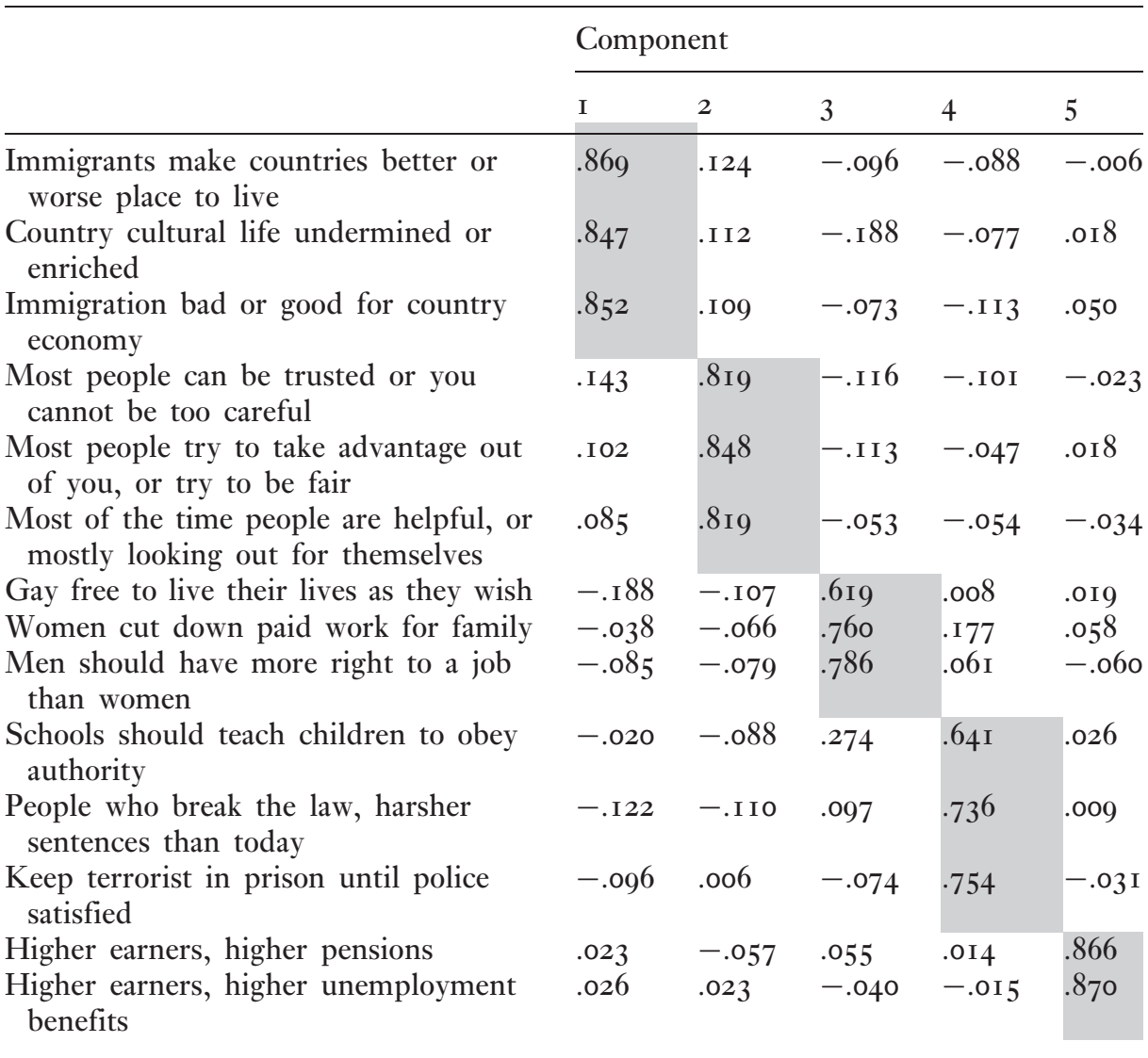

Note: Principal component analysis. Rotation: Varimax with Kaiser. Missing cases treatment: pairwise. KMO: 0.76 . Total explained variance with five factors: $67 \%$

control for the "ideological" determinants of welfare attitudes we follow the standard approach of using a question about the perceived fairness of inequalities:

Please say how much you agree or disagree with each of the following statements. "For a society to be fair, differences in people's standard of living should be small" (Answer scale from I-Strongly disagree to 5-Strongly agree).

To ease the comparison of the effects, we standardize this question to have mean $=0$ and Standard deviation $=\mathrm{I}$. Hence, indicators for multiculturalism, merit, authoritarianism, gender traditionalism, generalized trust and egalitarianism are measured in standard deviations to the European mean.

In the second part of the analysis, we use a macro variable indicating the welfare regime in which each country is included. We follow previous 
literature and classify countries as: Nordic (Denmark, Finland, Norway, and Sweden), Continental (Belgium, France, Germany, and the Netherlands), Liberal (UK and Switzerland), Mediterranean (Cyprus, Greece, Spain, and Portugal), and Eastern (Bulgaria, Czech Republic, Estonia, Croatia, Hungary, Latvia, Poland, Russia, Romania, Slovenia, Slovakia, and Ukraine). See theoretical section for references.

\section{Methods}

To find out to what extent values have similar effects on welfare attitudes across countries, we applied linear multilevel regression models with the index of support for state intervention in welfare as dependent variable, individuals' scores in the five factors as explanatory variables, individual level control variables (egalitarianism, sex, age, and education), random intercepts for the countries, and random slopes for each explanatory variable. To test the correspondence between welfare regimes and the values that affect support for the welfare state, we follow a two-step regression procedure. We carry out one Ordinary least squares (OLS) regression model in each country to compute the effects of the five subjective beliefs plus egalitarianism on "welfarism," and we resume the pattern of variation by means of OLS regression models with countries as cases, effects of values on "welfarism" as dependents, and welfare regime as explanatory variable (Table 4 ).

\section{Results}

To briefly describe the distribution of our working variables it is worth noting that the five subjective factors differ in extension from country to country, although the range of variation is wider for some of them (those with larger inter-country variation are gender traditionalism and authoritarianism). As for the dependent variable, the average of "welfarism" in the 26 countries is 7.77 (o-Io range). Europe is, hence, a strongly "welfarist" territory. ${ }^{5}$ Support for the welfare state is highest in the Southern European countries, followed by the Eastern countries, the Nordic, Continental, and Liberal welfare regimes in this order. Nevertheless, the pattern is blurred by within-group heterogeneity. Results are consistent with previous works (Svallfors, 2010; Taylor-Gooby, 2004).

To evaluate the relation between values and welfare attitudes we run multilevel regression models (Table 3) using the indicator of "welfarism" as our dependent variable, control variables (egalitarianism, sex, age, and

\footnotetext{
${ }^{5}$ Significant sectors of the European population are strongly welfarist, but only a small minority plainly rejects state intervention in the domain of welfare. About $70 \%$ of our sample has welfarism scores $\geq 7$, but only $2 \%$ present scores $\leq 4$.
} 


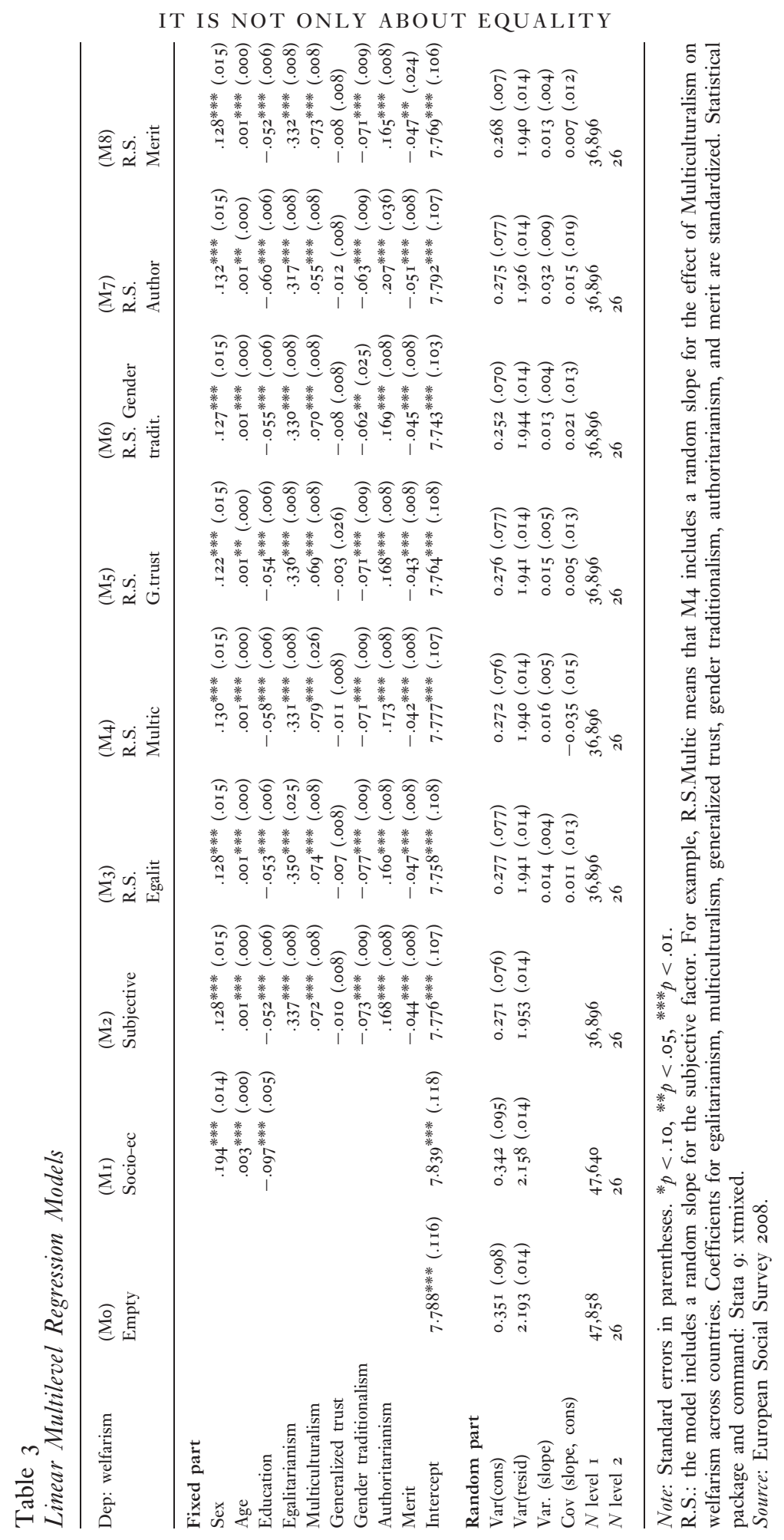


education), the indicators of values, random intercepts for the countries and random slopes for the effects of values on "welfarism."

In the first model (Mo), we can see that $14 \%$ of the total variation in Europeans' support for the welfare state is generated by characteristics of the countries where they live $[\operatorname{var}(\mathrm{cons}) / \operatorname{var}(\mathrm{cons})+\operatorname{var}(\mathrm{resid})]$. In MI, we appreciate that the socio-demographic variables show the same pattern than in previous studies. Education, in this case a proxy for self-interest, has a negative effect on "welfarism;" age has a small positive effect; and women are slightly more prone to support the welfare state than men are. In M2, we observe that, even controlling by each other, and by proxies for the two general determinants of welfare attitudes, four out of the five values we are studying do correlate with welfare attitudes, granting support to those scholars that argued about the importance of other subjective values and beliefs in explaining welfare opinions. As we will see later on, the lack of significance of generalized trust in this model is due to the fact that its effect is restricted to a limited set of countries (the Nordic ones). In addition, the inclusion of the subjective factors substantially improves our predictions. Variables included in Model 2 account for $22 \%$ of cross-country variance in support for the welfare state $\left(0.35 \mathrm{I}-0.272 / 0.35^{\mathrm{I}}=0.225\right)$.

Models $3^{-8}$ include random slopes for the effect of one value at a time. The first interesting result of that exercise is that the effect of most values varies, not only in size, but also in direction, depending on the country [see coefficients in row "Cov(slope)"]. Only egalitarianism has a positive effect on "welfarism" in all 26 countries.

The question that naturally arises is to what extent the positive association of these values with support for the welfare state benefits or endangers the overall legitimacy a welfare state can achieve. Regarding this issue, the covariance between the effect of a value and the aggregate support for the welfare state is only statistically significant for egalitarianism and multiculturalism. Welfare states particularly supported by people embracing multiculturalism tend to have lower legitimacy than the rest, whereas those particularly supported by egalitarian people tend to present higher levels of aggregate popular support. Regarding the other values, the lack of covariance between their effect and the average level of "welfarism" implies that the welfare state can achieve a high level of legitimacy based on very different moral grounds. Going back to the first two questions that guide our study, our data indicate that the five subjective factors identified in the literature do correlate with welfare attitudes even after controlling for each other, and for the two general determinants of welfare attitudes. However, none of these values has a consistent effect across all European countries.

Finally, to address our third question, we evaluate the correspondence between welfare regimes and the value structure that people use to develop 
opinions about the welfare state. The small number of cases in this analysis (only 26 countries) makes strongly advisable to follow a two-step regression procedure instead of adding country-level variables to the multilevel models (Lewis \& Linzer, 2005; Nelson, 2009). This procedure implies: (a) to carry out one OLS regression models by country to compute the effects of subjective beliefs on "welfarism" in each country (country coefficients computed from multilevel models have some "noise"); (b) to study the regression coefficients looking for similarities among the countries included in the same welfare regime; and (c) to resume the pattern of variation by means of six OLS regression models with countries as cases, effects of values on "welfarism" as dependents, and welfare regime as explanatory variable. Results are presented in Table 4 .

Resuming the general patterns found with this last analysis, and starting with the countries classified within the "Nordic welfare regime," we can say that this is the only area where "welfarism" is positively associated with generalized trust. This result is perfectly in line with Rothstein's theory on the formation of welfare attitudes. However, we also expected egalitarianism to be a stronger predictor of "welfarism" in the Nordic area than in other countries, and this is not true in the light of data. Regarding the other values, gender traditionalism and merit depress support for the welfare state, whereas multiculturalism increases it. The effect of our values in the Continental regime is quite similar to what we found in the Nordic one, but for the lack of association between generalized trust and welfarism. This similarity brings a second discordant result: we hypothesized that the contributory nature of welfare programs in Continental countries would turn meritocratic people into welfare state's supporters, but just like in Nordic countries, holding meritocratic values depresses support for the welfare state in this regime. The analysis of the Liberal welfare regime is severely restricted due to the small number of cases of this regime in Europe: The UK, with some limitations given the universalism of some its welfare programs (Mehrtens, 2004), and Switzerland. ${ }^{6}$ Considering these limitations, we see that the values associated with welfare support are quite close to those of Nordic or Continental types. The main difference is that egalitarianism shows a stronger association with "welfarism" in the Liberal regime than in the previous two. Again, this finding runs contrary to what we expected.

Results for Eastern Europe are more in line with our predictions: Egalitarianism and authoritarianism present a large and positive effect in support of the welfare state. In the East, holding authoritarian values increases support for the welfare state as much as holding egalitarian values. Additionally, it is the only area where having a traditional view on gender

\footnotetext{
${ }^{6}$ The classification of Switzerland in a welfare regime is not straightforward. Arts and Gelissen (2002) indicate that most empirical works have placed this country within the Liberal regime.
} 


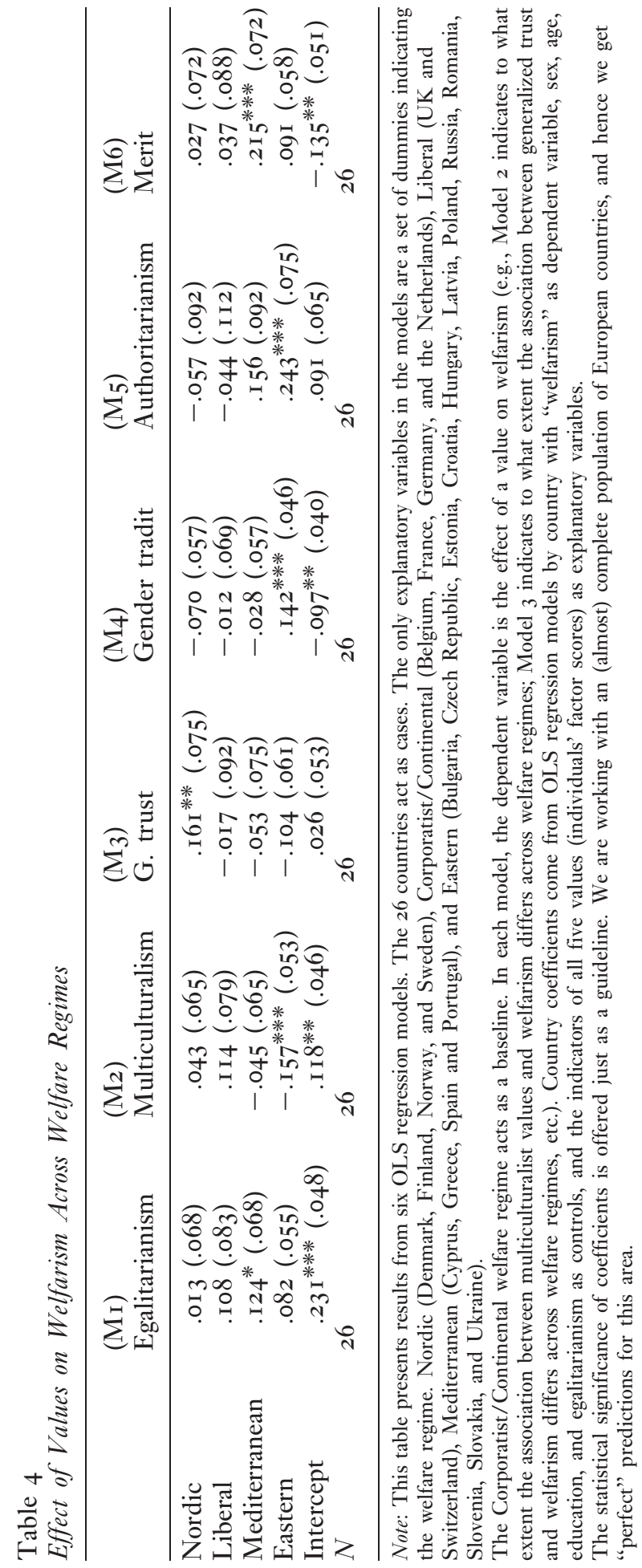

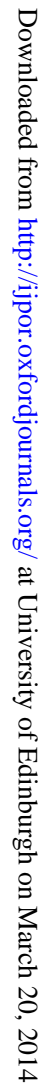


roles does not decrease welfarism. Patterns found in the Southern European welfare regime are also coherent with our hypotheses as: Both egalitarianism and meritocratic values promote support for state intervention in welfare, reflecting the mix between universal and contributory programs in these countries. Gender traditionalism depresses support for the welfare state but, contrary to expectations, the effect is not larger than in Nordic or Continental countries. Authoritarianism is positively associated with welfarism, although the effect is not as strong as in Eastern countries.

\section{Conclusion}

We have shown that the set of values and beliefs included in our analyses are part of the factors that citizens use to elaborate opinions on the desirability of social policies. All correlate with welfare attitudes, but their particular effect is context-dependent. Egalitarianism, included in our models as a controlling variable, is the only value with a significant positive effect in all countries, and is by far, the strongest predictor.

The five values and beliefs included in our study were extracted from a literature review on subjective factors that account for citizen's attitudes toward the welfare state. Our analyses confirm the results of previous work on the importance of subjective factors in understanding welfare attitudes. However, no relationship can be generalized to all countries, preventing the use of the same explanatory scheme to understand the legitimacy of the welfare state across Europe.

Additionally, we wanted to empirically evaluate Rothstein's arguments on the relationship between the design of the welfare state and its legitimacy. Specifically, we expected both egalitarianism and generalized trust to show a close connection to support for the welfare state in the Nordic countries. The fact that generalized trust promotes support for welfare only in these countries can be interpreted as a clear confirmation of his theory. Rothstein argues that universal systems are driven by the basic aim of non-discrimination among citizens, and following this idea we expected egalitarian values to be more strongly connected to welfare support in Social-democratic countries than in the other areas. Our results refute this hypothesis. In fact, egalitarianism is more important to predict attitudes toward welfare in Liberal welfare states than in the Nordic countries, what can be interpreted as being in contradiction with moral institutionalism assumptions. Alternatively, the problem may lie in equating the aims of "non-discrimination" and "equality." Notice that opposition to gender and ethnic discrimination is associated with supporting the welfare state in various regimes, but particularly so in the Nordic one (Table 4). 
In Continental, Mediterranean, and Eastern countries, we looked for a correlation between the guiding principles of welfare systems and the values associated with welfare support. Eastern and Mediterranean countries present patterns consistent with our hypothesis. Authoritarianism and egalitarianism correlate with positive attitudes toward welfare in the Eastern region, whereas in Southern Europe egalitarianism and merit promote support for the welfare state. Continental countries, on the contrary, do not fit our predictions. We expected merit to be positively associated with support for the welfare state in this regime because social benefits are distributed according to this principle. The relationship is actually the opposite, and people holding meritocratic values are less prone to support welfare programs both in Continental and in Nordic countries.

From our point of view, the moral institutionalism theory is strong and interesting enough to warrant future efforts to test its assumptions. However, we need more reflection on the mechanisms linking the characteristics of institutions with people's perceptions, and more fine-grained hypotheses concerning the value structure of welfare opinions under each type of welfare state.

\section{Acknowledgements}

The authors gratefully acknowledge the help of Celia Mayer in providing background information for the preparation of this article and of José Manuel Rojo in the verification of statistical procedures.

\section{Funding}

This article was written with funds from the projects WAE (CSO2008-02874E/SOCI), and SOLFCARE (CSO2OII-27494), financed by the Spanish National Plan on R\&D.

\section{References}

Achterberg, P., Houtman, D., \& Derks, A. (20II). Two of a kind? An empirical investigation of anti-welfarism and economic egalitarianism. Public Opinion Quarterly, 75(4), 748-76o.

Alesina, A., \& Glaeser, E. (2004). Fighting poverty in the US and Europe. Oxford: Oxford University Press.

Andreß, H. J., \& Heien, T. (200I). Four worlds of welfare state attitudes? A comparison of Germany, Norway and the US. European Sociological Reviem, I7, $337-356$.

Arts, W., \& Gelissen, J. (2002). Three worlds of welfare capitalism or more? A stateof-the-art report. Fournal of European Social Policy, I2, I37-I58. 
Bean, C., \& Papadakis, E. (I998). A comparison of mass attitudes towards the welfare state in different institutional regimes, I985-I990. International Fournal of Public Opinion Research, IO, 2 I I-236.

Blekesaune, M., \& Quadagno, J. (2003). Public attitudes toward welfare state policies. A comparative analysis of 24 nations. European Sociological Reviem, I9, 415-427.

Bonoli, G. (I997). Classifying welfare states: a two-dimension approach. Fournal of Social Policy, 26, 35 $\mathrm{I}-372$.

Breznau, N. (2010). Economic equality and social welfare: policy preferences in five nations. International Journal of Public Opinion Research, 22(4), 459-484.

Brugidou, M. (2003). Argumentation and values: an analysis of ordinary political competence via an open-ended question. International Fournal of Public Opinion Research, I5(4), 4I3-430.

Callegaro, L., \& Pasini, G. (2008). Informal care and labour force participation: the economics of family networks. In A. Börsch-Supan (Ed.), First results form the survey of health, ageing and retirement in Europe (2004-2007). Mannheim: Mannheim Research Institute for the Economics of Aging.

Converse, P. E. (1964). The nature of beliefs systems in mass publics. In D. E. Apter (Ed.), Ideology and Discontent (pp. 206-26r). New York: Free Press.

Dallinger, U. (2010). Public support for redistribution: What factors explain the international differences? Fournal of European Social Policy, 20(4), 333-349.

Deacon, B. (2000). Eastern European welfare states: the impact of the politics of globalization. Fournal of European Social Policy, IO, г46-г6г.

Deacon, B., Castle-Kanerova, M., \& Manning, N. (1992). The nem Eastern Europe: social policy past, present and future. London: Sage.

Duriez, B., Van Hiel, A., \& Kossowska, M. (2005). Authoritarianism and social dominance in Western and Eastern Europe. Political Psychology, 26(2), 299-320.

Eckhardt, W. (I99i). Authoritarianism. Political Psychology, I2(I), 97-I24.

Edlund, J. (I999). Trust in government and welfare regimes: attitudes to redistribution and financial cheating in the USA and Norway. European Fournal of Political Research, 35(3), 34I-370.

Esping-Andersen, G. (I990). The three morlds of melfare capitalism. Cambridge: Polity.

Esping-Andersen, G. (I999). Social foundations of post-industrial economies. Oxford: Oxford University Press.

Feldman, S. (I988). Structure and consistency in public opinion: the role of core beliefs and values. American Fournal of Political Science, 32(2), 416-440.

Feldman, S., \& Zaller, J. (I992). The political culture of ambivalence: ideological responses to the welfare state. American Fournal of Political Science, 36( I), 268-307.

Ferrera, M. (I993). Citizens and social protection. main results from a Eurobarometer survey. Brussels: Commission of the European Communities.

Forma, P. (I999). Interests, institutions and the melfare state: Studies on public opinion tomards the melfare state. Turku: National Research and Development Centre for Welfare and Health.

Forma, P., \& Kangas, O. (I999). Need, citizenship or merit: public opinion on pension policy in Australia, Finland and Poland. In S. Svallfors \& P. Taylor-Gooby (Eds.), The end of the melfare state? Responses to state retrenchment (pp. I6I-I89). London: Routledge. 
Fraile, M., \& Ferrer, M. (2005). Explaining the determinants of public support for cuts in unemployment benefits across OCDE countries. International Sociology, 20, $459-48$ I.

Gamson, W. A. (I992). Talking politics. Cambridge: Cambridge University Press.

Gelissen, J. (2000). Popular support for institutionalised solidarity: a comparison between European welfare states. International fournal of Social Welfare, 9, $285-300$.

Goerres, A., \& Tepe, M. (2010). Age-based self-interest, intergenerational solidarity and the welfare state. European Fournal of Political Research, 49, 8 I $8-85$ I.

Halvorsen, K. (2007). Legitimacy of welfare states in transition from homogeneity to multiculturalism: a matter of trust. In S. Mau \& B. Veghte (Eds.), Social justice, legitimacy and the melfare state (pp. 239-259). Aldershot: Ashgate.

Han, C. (2012). Attitudes toward government responsibility for social services: comparing urban and rural China. International Journal of Public Opinion Research, 24(4), 472-494.

Hofstede, G. (1980). Culture's consequences: International differences in mork-related values. London: Sage.

Hofstede, G. (I998). A case for comparing apples with oranges. International differences in values. In M. Sasaki (Ed.), Values and attitudes across nations and time (pp. I6-3 I). Leiden: Brill.

Hooghe, M., Reeskens, T., \& Stolle, D. (2007). Diversity, multiculturalism and social cohesion: trust and ethnocentrism in European societies. In K. Bantin, T. J. Courchene \& F. L. Seidle (Eds.), Belonging? Diversity, recognition and shared citizenship in Canada (pp. 387-409). Montreal: IRPP.

Houtman, D., Achterberg, P., \& Derks, A. (2008). Faremell to the Leftist Working Class. New Brunswick, NJ: Transaction Publishers.

Inglehart, R. (I990). Culture shift in advanced industrial society. Princeton: Princeton University Press.

Inglehart, R. (I997). Modernization and postmodernization: cultural, economical and political change in 43 societies. Princeton: Princeton University Press.

Iversen, T. (2005). Capitalism, Democracy and the Welfare State. New York: Cambridge University Press.

Kelsen, H. (1967). Pure theory of law. Berkeley: University of California Press.

Khoshkish, A. (I974). The concept of values: a sociophenomenological approach. Journal of Value Inquiry, 8, I-I6.

Korpi, W. (2000). Faces of inequality: gender, class, and patterns of inequalities in different types of welfare states. Social Politics, 7, I27-I9I.

Korpi, W., \& Palme, J. (I998). The paradox of redistribution and strategies of equality: welfare state institutions, inequality and poverty in the Western countries. American Sociological Reviem, 63, 66I-687.

Kymlicka, W. (2008). Multiculturalism, social justice and the welfare state. In G. Craig, T. Burchardt \& D. Gordon (Eds.), Social justice and public policy (pp. 53-76). Bristol: Policy Press.

Linos, K., \& West, M. (2003). Self-interest, social beliefs and attitudes to redistribution. European Sociological Reviem, I9, 393-409. 
Lipsmeyer, C. S., \& Nordstrom, T. (2003). East versus West: comparing political attitudes and welfare preferences across European societies. Fournal of European Public Policy, IO, 339-364.

Lewis, J. B., \& Linzer, D. (2005). Estimating regression models in which the dependent variable is based on estimates. Political Analysis, I3, 345-364.

Luo, X. (I998). What affects attitudes towards Government's role in solving unemployment? A comparative study of Great Britain and the United States. International Fournal of Public Opinion Research, IO(2), I2I-I44.

Manning, N., \& Shaw, I. (I998). The transferability of welfare models: A comparison of the Scandinavian and State Socialist models in relation to Finland and Estonia. Social Policy and Administration, 32, 572-590.

Marcum, C., \& Treas, J. (20I2). The intergenerational social contract revisited: crossnational perspectives. In M. Silverstein \& R. Giarrusso (Eds.), From generation to generation: continuity and discontinuity in aging families. Oxford: OUP.

Martínez-Herrera, E. (2004). Liberal nationalism, political confidence, and support for the melfare state. Evidence from Britain. EUI Working Paper SPS 2004/o8 http://cad mus.eui.eu/bitstream/handle/I8I4/2625/sps2004-08.pdf?sequence $=\mathrm{I}$.

Mehrtens, J. F. (2004). Three worlds of public opinión? Values, variation and the effect on social policy. International Journal of Public Opinion Research, I6(2), I I 5-I43. doi:Io. I093/ijpor/i 6.2. I I5.

Moreno, L. (2006). The model of social protection in Southern Europe: Enduring characteristics? Revue française des affaires socials, I, 73-95.

Nelson, M. (2009). An application of the estimated dependent variable approach: Trade Union members' support for active labor market policies and insider-outsider politics. International Journal of Public Opinion Research, 2I, 224-234.

Peffley, M. A., \& Hurwitz, J. (I985). A hierarchical model of attitude constraint. American Fournal of Political Science, 29(4), 87I-890.

Reeskens, T., \& van Oorschot, W. (2012). Disentangling the 'New Liberal Dilemma': On the relation between general welfare redistribution preferences and welfare chauvinism. International fournal of Comparative Sociology, 53, I20-139.

Reher, D. (1998). Family ties in Western Europe: persistent contrasts. Population and Development Reviem, 24, 203-234.

Rokeach, M. (I973). The nature of human values. New York: Free Press.

Rothstein, B. (1998). Fust institutions matter. The moral and political logic of the universal melfare state. Cambridge: Cambridge University Press.

Schwartz, S. (I992). Universals in the content and structure of values: Theoretical advances and empirical tests in 20 countries. In M. Zanna (Ed.), Advances in experimental social psychology (pp. I-65). New York: Academic Press.

Schwartz, S. (I994). Are there universal aspects in the structure and contents of human values? Fournal of Social Issues, 50, I9-45.

Sniderman, P. M., Brody, R. A., \& Tetlock, P. E. (I99I). Reasoning and Choice. Explorations in Political Psychology. New York: Cambridge University Press.

Sturgis, P., \& Smith, P. (2010). Assessing the validity of generalized trust questions: what kind of trust are we measuring? International fournal of Public Opinion Research, 22(I), 74-92. 
Svallfors, S. (I995). The end of class politics? Structural cleavages and attitudes to Swedish welfare policies. Acta Sociologica, 38, 53-74.

Svallfors, S. (I999). Political trust and attitudes towards redistribution. A comparison of Sweden and Norway. European Societies, I, 24I-268.

Svallfors, S. (2003). Welfare regimes and welfare opinions: A comparison of eight western countries. Social Indicators Research, 64, 495-520.

Svallfors, S. (2010). Public attitudes. In F. G. Castles, S. Leibfried, J. Lewis, H. Obinger \& C. Pierson (Eds.), The Oxford handbook of the melfare state (pp. 24I-25I). Oxford: Oxford University Press.

Taylor-Gooby, P. (2004). Open markets and welfare values Welfare values, inequality and social change in the silver age of the welfare state. European Societies, 6(1), 29-48.

Taylor-Gooby, P. (2005). Uncertainty, trust and pensions: The case of the current UK reforms. Social Policy \& Administration, 39(3), 217-232.

van Oorschot, W., \& Arts, W. (2005). The social capital of European welfare states: the crowding out hypothesis revisited. Fournal of European Social Policy, I5(I), $5^{-26 .}$

van Oorschot, W., \& Meuleman, B. (2012). Welfarism and the multidimensionality of welfare state legitimacy: Evidence from The Netherlands, 2006. International Journal of Social Welfare, 2I, 79-93. 